\title{
静脈麻酔剤メトへキシタール・ナトリウムの麻酔作用 ならびに呼吸血圧作用
}

\author{
九州䨑科大学菌科薬物学教室 (主任 : 吉村泰治教授) \\ 黑木 賀代子・村上 雄 次 - 吉 村 泰 治 \\ 九州歯科大学第 1 日腔外科学教室（主任：山田長敬教授）
}

西正勝

昭和 53 年 7 月 18 日受付

\begin{abstract}
Observation of the Effect of Methohexital-Na (Brevital ${ }^{\circledR}$ Sodium), an Intravenous Anesthetic, on the Central Nervous, the Respiration and the Cardiovascular System
\end{abstract}

By

Kayoko Kuroki, Yuji Murakami and Taiji Yoshimura

Department of Dental Pharmacology (Chief : Prof. Taiji Yoshimura)

Masakatsu Nishi

First Department of Oral Surgery (Chief : Prof. Nagayoshi Yamada)

Kyushu Dental College, Kitakyushu, Japan

Examinations of the effect of Methohexital-Na were made in rabbits and its anesthetic action was observed by Girndt-Magnus's method. The action on the respiration and blood pressure were recorded by a tambour and a mercury manometer.

The results were as follows.

1. Methohexital-Na did not cause narcosis in the dose of $1 \mathrm{mg} / \mathrm{kg}$, but in the dose of $5 \mathrm{mg} / \mathrm{kg}$ deep anesthesia was obtained. The duration of anesthesia lasted only 2 to 3 minutes. After 6 to 8 minutes, the animal recovered consciousness.

2. In the dose of $5 \mathrm{mg} / \mathrm{kg}$, the respiration and blood pressure were arrested sufficiently. But these depressions soon passed away. After 4 to 5 minutes, the animal recovered consciousness.

3. Narcotic effect of Methohexital-Na was influenced to some extent by its injection speed. When injection was given speedily, narcosis became deeper and depressions increased. But there was no distinct difference whether the injection speed was in 10 or in 60 seconds. Even injection in 10 seconds brought about above mentioned symptoms but it lasted only 10 to 20 seconds.

In view of the foregoings, it is considered that Methohexital- $\mathrm{Na}$ is an adequate anesthetic without any apparent side-effect in narcotic dose $(5 \mathrm{mg} / \mathrm{kg})$ injected in the speed of about 30 seconds. 


\section{緒言}

最近静脈麻酔剂として新たにバルビツール酸誘導体メ トヘキシタールが開発された。本剤は作用発現が迅速で あり，持続がきわめて短かく，切開や抜歯時等の麻酔に は好適であると言われている。

静脈麻酔㨈はすべてが解毒の速いものである。このた めにその作用には注入速度が強く影響し，あまりに徐々 に注入すれば麻酔は現われず，また，あまりに急速に注 入すれば麻酔は強くなるが延鹃の麻酔まで惹起し，呼吸 循環器に障害を起す心配がある.とのことはメトへキシ タールに扑ても同様と思われる。

ここに著者らはメトへキシタールの麻酰作用ならびに その呼吸循環器抑制作用が注入速度によってどのように 影響を受けるかを明らかにしたいと考え，ての実験を行 なった。

\section{実験材料ならびに方法}

\section{実験材料}

動物は体重 $1.7 \mathrm{~kg} \sim 3.7 \mathrm{~kg}$ (平均 $2.2 \mathrm{~kg}$ ) の家鬼を合計 40 羽, 雌雄の別なく使用した。

メトヘキシタール製剂は Brevital ${ }^{\circledR}$ sodium（米国 Lilly社製）を使用した・Brevital ${ }^{\circledR}$ sodium はメトへ キシタール・ナトリウム $500 \mathrm{mg}$ 抢よび無水炭酸ナトリウ ム $30 \mathrm{mg}$ を含有する白色結晶性粉末で，用時 $50 m \ell の$ 注射用 蒸留水を加えるように作られたバイアル瓶入り製剤であ る. その水溶液は室内にて少くとも 6 週間は安定である と言われているが，実際には密栓をせずに置くと数週 間で結晶を析出した。とのため著者らはBrevital ${ }^{\circledR}$ sodium 粉末を使用の直前に溶解した。供試用溶液の濃 度は $1 \%$ した。

実験方法

麻酥作用の観察には，無麻酔無拘束の家鬼にメトへキ シタールを耳静脈より注入した，麻酔深度の測定には Girndt, Magnus らの方法を参考にして特に体位，姿 勢, 歩行を主として用いた。

呼吸循環器系に対する作用の観察には，家兔を無麻酔 の下に背位に固定し，呼吸は気管カニューレ，タンブー ルにより，血圧は頸動脈圧を水銀マノメーターにより描 記測定した．薬物は一側の股静脈にあらかじめ乗入固定 しておいたポリエチレン管から所定の速度で注入した。

\section{実 験 成}

\section{A . 麻酔作用}

1.メトヘキシタール・ナトリウムの $1 \%$ 溶液を用 い, 毎秒 $0.2 \mathrm{ml}$ の速度で $1 \mathrm{mg} / \mathrm{kg}$ を耳静脈より注入する
と, 注入直後に後半身の他動的側位からの整復が少し遟 れるのが認められた。しかし，動物の体位，姿勢ならび に歩行にも，また，反射にも変北は認められなかった。 他に 2 例について実験したが，結果はほぼ同様であっ た。

次に $5 \mathrm{mg} / \mathrm{kg}$ 同様に静注すると，動物は直ちに全身 側位となり，全骨格筋の緊張は下降し眼球震盪が出現し たが，角膜反射および耳殻反射は軽度に抑制されたのみ で，刺激を加えれば反応は現われた。胸部運動(呼吸) は一時弱く遅くなった。しかし，約 3 分後に動物は頭部 を持ち上げるようにし，約 4 分後に前半身は正常位をと りうるようになった。てての後間もなく後半身も正常位を とるようになり，他動的側位からの整復も容易となり， 自発的に運動するようになった．注射後 6 〜 8 分後には 体位，姿勢，歩行はほとんど完全に回復した。

他に 2 例について同じくメトヘキシタール・ナトリウ ム5 mg/kgを注射したが，いずれもはぼ同様の結果を示 した・ただし，眼球震盪は見られなかった。

2. 次に体重 $2 \mathrm{~kg}$ 雌家鬼を使用し，乙れにメトヘキ シタール・ナトリウム $5 \mathrm{mg} / \mathrm{kg}$ 在 5 秒間，30秒間および 60 秒間の 3 種の速度で注入し，注入速度と麻酔作用とを 比較した。この場合，第 2 回目以後の注射は前に応用し たメトへキシタールが完全に解毒されるのを待って，す なわち 5 時間以上を経過後に行なった。

$5 \mathrm{mg} / \mathrm{kg}$ を 5 秒間に注入すると，動物は全身側位とな り刺激を加えても反応なく，他動的に正常位にしても正 常位をとり得ず，直ちに側位となった。しかし，注射後 約 3 分を経過すると家鬼は頭部のみを挙上しようと動か し始め， $3 \sim 4$ 分後には前半身が正常位をとるようにな り, $4 \sim 5$ 分後には後半身も側位からの整復が可能とな り，間もなく自発的に運動するようになったが，失調性 であった．注射開始後 6 分半で運動失調は認められなく なり，体位，姿勢，歩行もほとんど完全に回復した。

その後，約 6 時間放置してこの家兔に同じく $5 \mathrm{mg} / \mathrm{kg}$ のメトヘキシタール・ナトリウムを今度は注射時間を長 くして30秒間で注入した。すると動物は注射後直ちに全 身側位をとり筋の緊張も完全に消失して，5秒間に注入 した場合とほとんど同様の症状を示した。この状態は注 射開始後約 3 分まで持続し，その後動物は頭部のみを動 かし始め, 頭部, 前半身, 全身というふうに次第に整復 し，5秒間に注入した場合とほぼ同様の経過を辿り6 分 後にはほとんど正常に復し，体位，姿勢，歩行も正常と なった。

次に 1 日を経て同じ家鬼に同量のメトヘキシタール・ 
ナトリウムを60秒間に注入した．注射を終ると動物は直 ちに全身側位となり，刺激に 対する反応もほとんどな く，症状は前の 5 秒間および30秒間に注入した場合と区 別はできなかった。また，症状の回復も同様に現われ た。しかし，乙の場合には回復は少し早く，注射開始後 約 5 分経過するとほとんど完全回復が認められた。

以上の実験を 2 回繰り返し行なった. 第 2 回目の実験 でもほとんど同じ様な結果が得られた。実験結果を表示 すると表 1 のようになる.

表 1 種々の速度で注入したメトヘキシタール・ナト リウムの麻醉作用

用量： $5 \mathrm{mg} / \mathrm{kg}$

動物：家兔

\begin{tabular}{|c|c|c|c|c|c|}
\hline \multicolumn{3}{|c|}{ 注入速度 } & 用量/ 5 秒 & 用量 $/ 30$ 秒 & 用量 $/ 60$ 秒 \\
\hline \multirow{5}{*}{ 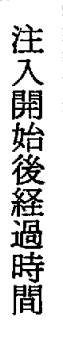 } & 麻 & 4 & $2^{\text {分 }}: 50^{\text {秒 }}$ & $2^{\text {分 }}: 50^{\text {秒 }}$ & 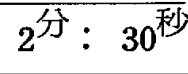 \\
\hline & 酔 & 3 & $3: 29$ & $3: 25$ & 10 \\
\hline & 深 & 2 & $4: 45$ & $4: 20$ & $3: 40$ \\
\hline & 度 & 1 & 5 & $5: 06$ & $: 30$ \\
\hline & 完毛 & 回復 & $: 15$ & $: 00$ & 4 \\
\hline
\end{tabular}

表 1 にみられるように,メトヘキシタール・ナトリウ 么は同一麻酔量を 5 秒間，30秒間および60秒間のいずれ かの速度で注入しても，深麻酔持続時間は注射開始後 2 分50秒で，それらの間に差異は見られない。しかし，麻 酔からの覚醒をみると完全回復までに要する時間には差 異を生じた. 5 秒間の注射では回復に 6 分15秒を要し， 30 秒の注射では 6 分， 60 秒の注射では 4 分50秒をそれぞ れ要している，すなわち，注入速度が緩やかになるほど 麻酔の回復はいくぶん速くなる傾向が認められた。

次に表 1 より，麻酔作用持続時間および作用回復時間 を注入終了直後からの経過時間として求めてみた．5 秒 間に注入した場合では深麻醉持続時間は 2 分 45 秒， 30 秒 間の注入では 2 分 20 秒, 60 秒間の注入では 1 分 30 秒とな り，回復時間は 5 秒間注入では 6 分 10 秒, 30 秒間注入で は 5 分 30 秒， 60 秒間注入では 3 分 50 秒となった(図 1)。

B 、呼吸扝よび血圧に対する作用

家鬼にメトヘキシタール・ナトリウム $5 \mathrm{mg} / \mathrm{kg}$ を急速 に（約 $5 \sim 7$ 秒間で）注入した場合と緩徐に（30秒間ま た60秒間で）注入した場合の呼吸および血圧に対する作 用を比較した。

1. 急速に注入した場合

（第 1 例） $2.3 \mathrm{~kg}$ 雌

メトヘキシタール注入後, 呼吸は一時（約15秒間）運

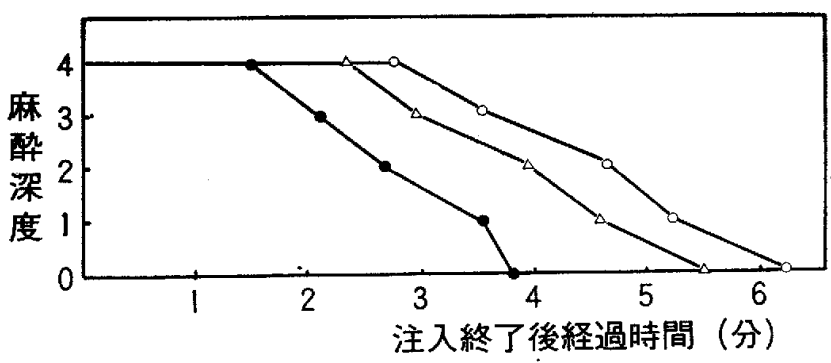

図1 メトヘキシタール・ナトリウムの注入速度と麻 酔持続時間 用量： $5 \mathrm{mg} / \mathrm{kg}$ 動物：家鬼 注入速度：O用量 $/ 5$ 秒 $\triangle$ 用量 $/ 30$ 秒 $\bigcirc$ 用量 $/ 60$ 秒

動を停止したが，間もなく振幅の大きい数の少ない呼吸 を始めた。その後，掁幅は次第に縮小し呼吸数は増加し たが，正常時に比較すると振幅は小さく，数も少なかっ た. 乙の呼吸抑制は10分後もな打続き，その後僅かに振 幅は増大したが，40分後も旧には復しなかった。

血圧は注入と同時に急速に下降し，15秒後に最低值 $50 \mathrm{mmHg}$ を示した。 その後，急速に回復し始め，4 分 後には正常に復し， 5 分後より 7 分後までは正常時より も軽度の上昇が見られたのち回復した。

(第 2 例) $2.0 \mathrm{~kg}$ 雌

注入と同時に呼吸は振幅を縮小し, 数も堿じたが, 間 もなく振幅の大きい数の少ない呼吸へと移行した４ 4 分 後, 呼吸数はほほ旧に復したが, 振幅増大はその後も続 いた．20分後には振幅も正常に近くなったが，呼吸数は むしろ正常時よりも多くなった。

血圧は注入後直ちに下降し，下降度は $25 \mathrm{mmHg}$ に達 したが，30秒後には回復に向かい，2 分後には完全に回 復し，引き続き軽度の上昇が現われた。しかし，4分後 には上昇も回復して正常值をとった.

（第 3 例） $2.6 \mathrm{~kg}$ 雃

呼吸は注入と同時に一時停止し，15秒後に運動を開始 したが，初めは振幅が小さく，呼吸数は強く減少した。 やがて振幅は増大し始め， 5 分後には正常近くまで回復 したが，運動数はなお軽度の減少を続けていた１0分後 も同様で20分後には振幅の増大と共に呼吸数もかなり回 復した。

血圧は，注入と同時に急速に下降し始め，下降度は 40mmHgに達した。しかし，乙れも10秒後には回復し 始め，1分後にはほぼ回復した，その後，軽度の上昇が みられたが，5 分後にはほぽ正常に復した。

他に 6 例の 家鬼に対し，同量を同様に 急速に 注入し た.いずれの例に扔いても呼吸は一時的に運動を停止す るか，あるいは振幅の著しい縮小を示し呼吸数はかなり 
著明に減少した。しかし，強い呼吸抑制は一時的で，間 もなく回復に向い，中には $2 \sim 3$ 分後にすでにほとんど 正常に近く回復したものもあった。

血圧は注入と同時に急激な下降を示し，下降度は弱い もので30 mmHg, 強いものでも $40 \mathrm{mmHg}$ で, てれらの 下降も間もなく回復し始め，3〜4分で旧に復し引き続 き軽度の一時的上昇を起したのち, 正常に復した。中に は一度下降した血圧が 1 分半後にはすでに正常值以上に 上昇し，20分後に至ってもなお上昇を続けているものも あった。

以上のようにメトヘキシタール・ナトリウムは急速に 注入すると呼吸は一時的に停止し, 血圧は急速に強く下 降するが，いずれも持続は著しく短い，すなわち，呼吸 は注入直後は著明に抑制され，振幅縮小，運動数减少を 伴なうが，乙の著明な抑制は一時的（約15秒程度）で間 むなく回復に向かう。しかし，回復速度は遅く，大多数 例では20〜40分後においても軽度の運動数減少を示して 抢り,完全には回復していない。

血圧は注入を同時に起る強い下降が20秒後にはすでに 回復に向加， $3 \sim 4$ 分後には回復し，後一時的に正常 值よりも高い值をとる. この上昇も20４0分後に旧に復 した例が大多数であった。

2. 30秒間で注入した場合

（第 1 例） $2.0 \mathrm{~kg}$ 雌

注入後, 直ちに呼吸は振幅を縮小儿運動数も減少し た. この抑制作用も徐々に回復し始め， 6 分後には振幅 はかなり回復し，運動数は正常近くまで回復した。

血圧は注入後, 徐々に下降し, 30秒後には下降度最低 值 $(50 \mathrm{mmHg})$ 亿達した。しかし，血圧は直ちに回復 し始め, 1 分半後には正常近くに復し， 7 分後にはほ之 んぞ正常值に戻った。

(第 2 例) $2.0 \mathrm{~kg}$ 雌

この例でも呼吸運動は抑制され，振幅の縮小および運 動数の減少がみられた。しかし，強い抑制は間もなく消 失し, 7 分後に振幅は正常に復し， 20 分後には運動数も ほとんぞ回復した。

血圧は, 注入と同時に下降し始め, 30秒後に最低に達 し，下降度は $45 \mathrm{mmHg}$ であった。しかし，間もなく回 復に向かい，3分後にはほとんぞ正常近くまで回復し た。

\section{（第 3 例） $2.0 \mathrm{~kg}$ 雄}

この例では, 注入後呼吸運動が一時停止した．25秒後 に運動を再開し，間もなく振幅は強く増大した，呼吸数 は始めは著しく少なく，3 分後より徐々に增加し始めた
が，20分後においても正常より少なかった。

血圧は軽度の下降（下降度は $7 \mathrm{mmHg}$ ）を示し，回 復も速やかで 1 分半後には正常に復し， 2 分半から 6 分 までは軽度であるが，正常以上の值をとった。

その他 8 例について同一実験を試みた。いずれの例に 抢いても，呼吸は抑制され，強い運動数減少（一時的停 止）を起したものが 2 例あった，その場合に呼吸振幅は 常に増大した。その他の 6 例においては呼吸数減少は弱 かった. 回復は 4 例においては $4 \sim 5$ 分で呼吸はほとん ど正常に復し他の 4 例では $20 \sim 40$ 分後も軽度の抑制が続 いた。

血圧下降は 1 例では $40 \mathrm{mmHg}$ の下降度を示したが， 他例では20〜30mmHgであった，回復は早いものでは 1 分半, 遅いものでも 4 分でほほ正常に復した。この場 合，回復前に軽度の上昇がみられたものは 1 例だけであ った。てのように30秒間で注入すると急速に注入した場 合に比較して呼吸運動抑制および血圧下降は弱く，作用 持続も短いようであった。

3. 60 秒間で注入した場合

(第 1 例) $2.2 \mathrm{~kg}$ 雌

呼吸は注入開始後 54 秒で強い運動数減少と振幅増大を 起し，乙れが約 40 秒間持続したのち，正常に復した。

血圧は注入後間もなく徐々に下降し始め，70秒後に最 低值（下降度は $18 \mathrm{mmHg}$ ) となり，注入開始後 2 分で はほとんど正常に復した。

(第 2 例) $2.3 \mathrm{~kg}$ 雌

呼吸は注入開始後 20 秒経過すると振幅を縮小し 3 分後 より徐々に回復に向い 7 分後にはほぽ正常となった。呼 吸数は僅かに減少したのみであった.

血圧は注入開始後 30 秒より下降し始め下降度は $30 \mathrm{mmHg}$ に達したが, 直ちに回復に向い， 3 分後には 正常に復した.

（第 3 例） $1.9 \mathrm{~kg}$ 雌

本例では，呼吸は注入開始後 40 秒より振幅を縮小儿間 もなく運動数も減少したが 3 分後には呼吸運動はかなり 回復し， 7 分後には回復は更に強くなったが，なお正常 には達しなかった。

血圧は注入後 1 分 30 秒で最低值（下降度は $30 \mathrm{mmHg}$ ) を示したが，乙れも直ちに回復し始め 4 分後にはほほ正 常近くになった.しかし, 完全回復は10分後においても なお認められなかった。

以上の他に 6 例の家鬼で同様の実験を繰り返した。そ の1例に扔いては, 呼吸の一時的 (42秒間) 停止を起し たが，4 例では呼吸運動の振幅縮小および運動数減少を 
1. 急速に注入した場合（用量/ 5 秒）
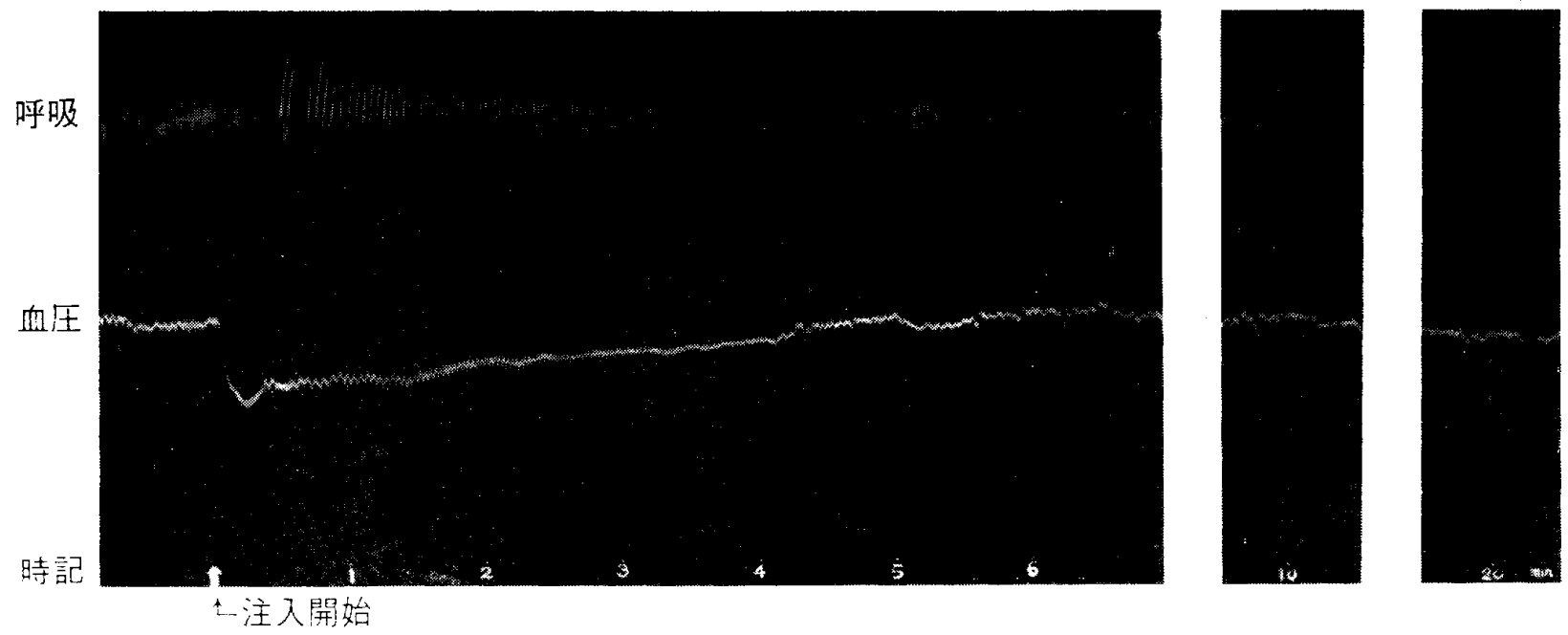

2.やや緩徐に注入した場合（用量/30秒）
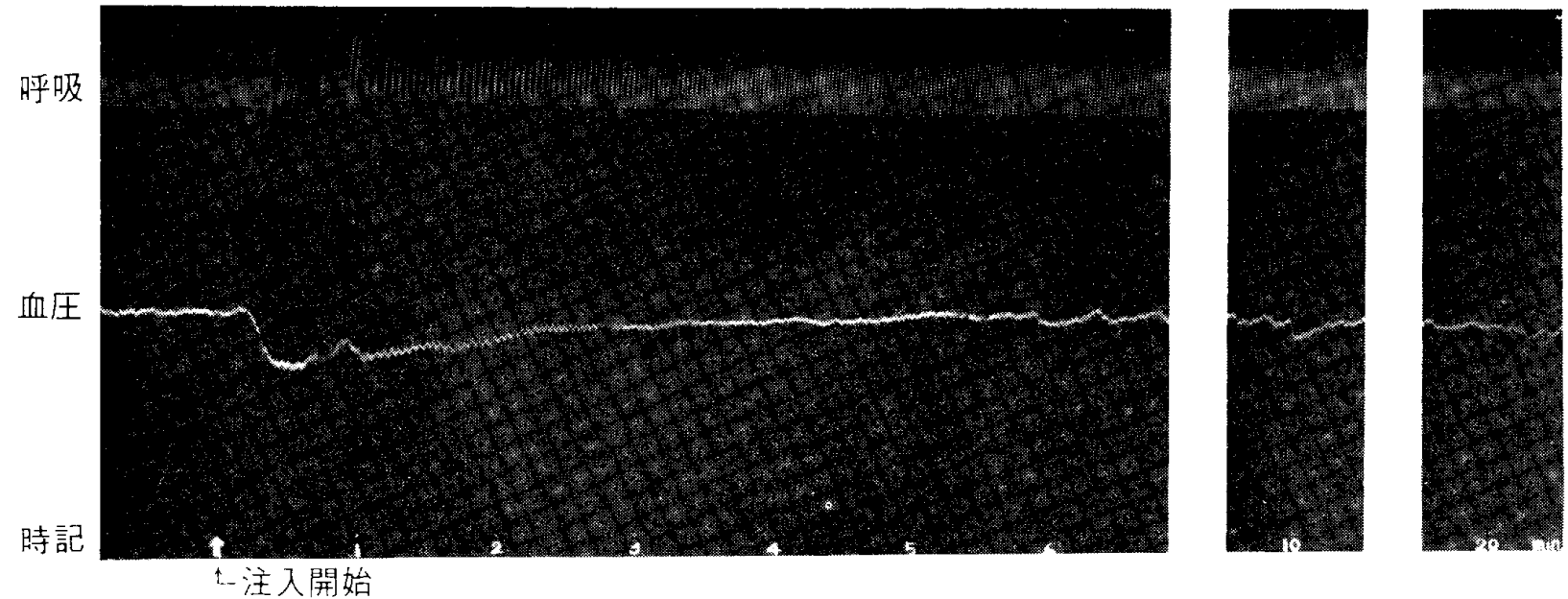

3. 緩徐に江:入した場命 (用是/60秒)
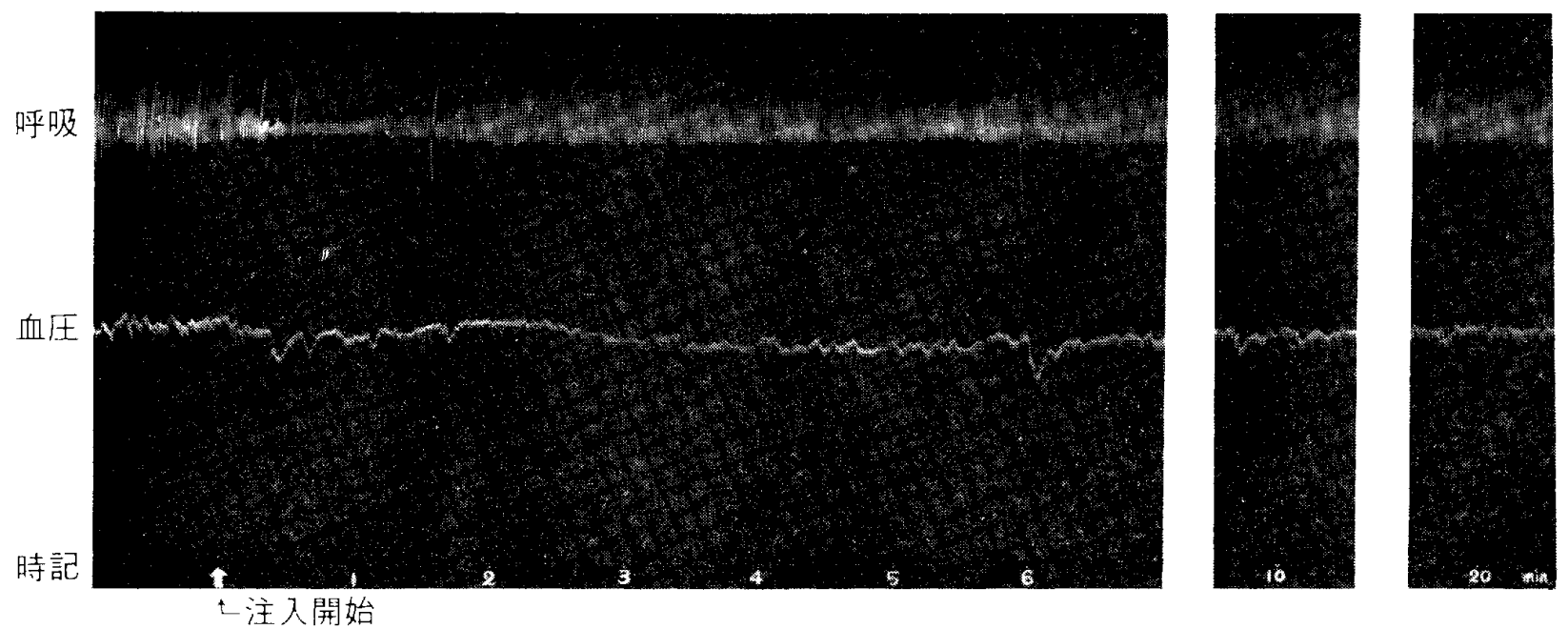

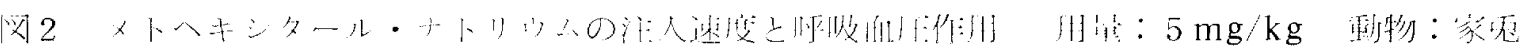


認め, 残りの 1 例では振幅縮小のみで，運動数減少は認 められなかった．血圧はいずれの例でも注入後一時的に 下降し，下降度は最も大きいもので $30 \mathrm{mmHg}$ に達した が，最も小さい2 例では $10 \mathrm{mmHg}$ 前後であった．血圧 下降の持続は長くて 3 分間，多くは 2 分間以内でほぽ 正常值に回復した. 1 例ではその後正常值よりも約 $10 \mathrm{mmHg}$ 程度の上昇が現われた。

以上のように60秒間で注入した場合も呼吸抑制および 血圧下降は出現するが，急速に注入した場合に比較する といずれも作用は軽度である。

次にメトヘキシタール・ナトリウム $5 \mathrm{mg} / \mathrm{kg}$ を 5 秒 間，30秒間および60秒間でそれぞれ注入した場合の呼吸 血圧変化の代表例を挙げた（図 2 ）。

\section{考察}

A・メトヘキシタール・ナトリウムの麻醐作用

家鬼ではメトヘキシタール・ナトリウム $1 \mathrm{mg} / \mathrm{kg}$ を静 注しても麻醉作用は現われず，5 $\mathrm{mg} / \mathrm{kg}$ 考用いれば 2 3 分持続する深麻酔が起ったことは既述の通りである.

城戸ら"によれば，同じく家鬼を用いてメトヘキシタ ール・ナトリウム $15 \mathrm{mg} / \mathrm{kg}$ および $25 \mathrm{mg} / \mathrm{kg}$ の静注により深 休酔を起すことを認め，その持続時間は $15 \mathrm{mg} / \mathrm{kg}$ では 1 〜 1.5分, $25 \mathrm{mg} / \mathrm{kg}$ では 4 〜分となっている. ての結果 と著者らの結果とはかなり異っているが，乙れは城戸ら がさらに少量のメトヘキシタール・ナトリウムの作用に ついて観察を行なわなかったためと思われる.

一方，三川"21はメトヘキシタール・ナトリウムの鎮痛 作用を観察し，乙れが $5 \mathrm{mg} / \mathrm{kg}$ では 1 分 45 秒， $7 \mathrm{mg} / \mathrm{kg}$ で は 2 分 45 秒， $10 \mathrm{mg} / \mathrm{kg}$ では 5 分 02 秒にわたり疼痛刺激反 応（腹部皮膚の小切開および尾部のClamping test）の 消失することを見ている．鎮痛作用はおううくその麻醉 作用と考光られ，それが $5 \mathrm{mg} / \mathrm{kg}$ で現われていることは メトヘキシタール・ナトリウムは $5 \mathrm{mg} / \mathrm{kg}$ で深麻酔を起 すものと見てよいから著者らの実験結果と合致するもの である。

貫 ${ }^{3,4}$ 'はチオペンタール・ナトリウムは $5 \mathrm{mg} / \mathrm{kg}$ で深 麻酔を起し，ヘキソバルビタール・ナトリウムより 2 倍

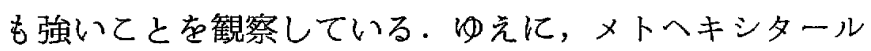
・ナトリウムもチオペンタール・ナトリウムと同程度の 強さを有するものと言えるが，作用持続はそれより少し 短いようである。

B ～注入速度による麻酔作用の差異

メトヘキシタール・ナトリウム $5 \mathrm{mg} / \mathrm{kg}$ 京 5 秒間, 30 秒間および60秒間に静注した場合の麻酔作用は実験成績
に述べた通りで，深麻酤持続時間は注射開始後いずれも 2 分50秒で注入速度による差異はほとんど認められなか った。しかし，注射終了後からの作用持続時間を比較す ると注入速度の速い場合が長く注入速度の遅い場合は短 い.また，完全に正常に復するまでの時間は注入を徐々 に行なった場合の方が短い．乙れはての薬物の解毒が速 いため，注入を行なっている最中にも解毒が起り，緩徐 に注入した場合には注入後の森酔作用持続は短くなり， 完全回復も早く起ると思われる．急速に注入すると急激 な血中濃度の上昇により中枢神経は強く抑制され，その 機能回復にも時間を多く要するようになるのであろう。

著者らの実験で注入速度を変えて 5 秒間， 30 秒間およ び60秒間と変化させても，注入終了時にはすでに深麻酔 を起し，その間の差異は見られなかった。しかし，その 解毒の速やかなととを考慮すれば，注入速度を遅くすれ ば作用発現も実際は遅くなるものと思われ，また，注入 速度をさらに遅くすればついには麻酔も起らなくなるも のと考えられる。

C. 注入速度に上る呼吸血圧作用の差異

メトヘキシタール・ナトリウムを静注すると注入開始 とともに呼吸は抑制され血压は下降する．特に注入速度 の速い場合には呼吸は一時的に運動を停止し, 血圧は急 激に下降し, 強い下降度を示す.また, 呼吸抑制, 血圧 下降の回復も注入速度の速いほど遅くなった。

てのように注入速度を大きくすれば麻酔作用および呼 吸血圧作用は強くなる. しかし, 急速注入した場合で も，呼吸血圧の強い抑制は一過性であり，10〜20秒後に は回復に向うので臨床的にはそれはど重篤な症状を招く とは考えられない。

むしろ，あまりに緩徐に注入すれば充分な麻酔強度が 得られなくなるのではないかという危惧がある.

\section{結論}

メトヘキシタール・ナトリウムを家象に静注し, 麻酔 作用ならびに呼吸血圧に対する作用を観察し, さらにそ れらに及ぼす注入速度の影響を検討し，次の結論が得ら れた。

1. 家兔では $1^{\mathrm{mg} / \mathrm{kg}}$ 投与では麻酔作用は現われなか つたが， $5 \mathrm{mg} / \mathrm{kg}$ では深麻醉を起した。深麻酔の持続は $2 \sim 3$ 分間で注射開始後 $6 \sim 8$ 分に作用は消失した.

2. メトヘキシタール・ナトリウムは $5 \mathrm{mg} / \mathrm{kg}$ の静注 で乎吸および血圧に対して抑制作用を呈したが著明な抑 制は一過性であった．その後軽度の抑制が続くがてれも $4 \sim 5$ 分でほぼ正常に復した。 
3. メトヘキシタール・ナトリウムの麻醉作用ならび に呼吸血圧作用は注入速度によって影響され，注入速度 を速くすれば麻醉作用は強くなり，呼吸抑制および血圧 下降作用も強くなり，乙れらの作用持続時間も長くなっ た、ただし，注入速度を10秒にしても60秒にしてもその 差は比較的少なく，注入速度が大である場合にみられる 強い呼吸抑制ならびに血圧下降は10〜20秒にすぎなかっ た.

4. 以上のてとから考えれば実際において麻酔量を30 秒前後で注入すれば作用もよく現われ，強い障害も起さ ないであろう。

稿を終るにあたり，終始御指導と御校閲を賜わりまし た貫文三郎九大名誉教授ならびに実験に御協力頂いた本 学歯科薬物学教室前助手前山博子, 柳元久美子の両氏に 深甚なる謝意を表します。

\section{文献}

1）城戸良之助 - 広瀬勝己也：Methohexital-Na の中 枢神経及び呼吸血圧作用, 応用薬理 $2: 272$ $-279,1968$.

2 ）三川 宏: 新静脈麻酼剤 propanidid 及び methohexital sodium の比較研究一特に呼吸, 循環 器系に及ぼす影響について, 麻酔 $18: 305 一$ $315,1969$.

3 ) 貫文三郎: 薬理学, 福岡大学薬学部薬理学教室, 福 岡, 1970 .

4）貫文三郎：静脈内麻酔骩 オウロパン・ナトリウム 亿就て，東京医事新誌 3048：2356-2361， 1937. 